\title{
Simulation of trans boundary wastewater resource management scenarios in the Wadi Zomer watershed, using a WEAP model
}

\author{
Eyad Y. Yaqob ${ }^{1 *}$, Rashed Al-Sa ${ }^{2}{ }^{2}{ }^{2}$, George Sorial $^{1}$, Makram Sudian ${ }^{1}$ \\ ${ }^{I}$ Department of Biomedical, Chemical, and Environmental Engineering (BCEE) College of Engineering and Applied Science \\ University of Cincinnati, Ohio, USA \\ ${ }^{2}$ Institute of Environmental and Water Studies Birzeit University, POB 14, Birzeit, West Bank, Palestine \\ *Corresponding author E-mail: yaqobey@ mail.uc.edu
}

Copyright $\odot 2015$ Eyad Y. Yaqob et al. This is an open access article distributed under the Creative Commons Attribution License, which permits unrestricted use, distribution, and reproduction in any medium, provided the original work is properly cited.

\begin{abstract}
Water resource shortages are always a challenge for Middle Eastern countries in general and for the Palestinian Authority in particular. For over 20 years in Palestine, political factors and a lack of control over water resources have exacerbated the water problem there, seriously affecting water resources, in terms of quality and quantity. This research presents one of the applications of the Water Assessment and Planning (WEAP) model in the Nablus and Tulkarm watershed. The model is applied in evaluating and analyzing the existing balance and the role of treated wastewater and anticipates future scenarios for the management of water resources, taking into account the policies and operating the various factors that may affect the demand and the impact of treated wastewater on the water budget until 2035.

The results showed that the amount of treated wastewater in the study area will reach 16 MCM by 2035 . The agricultural sector needs $17 \mathrm{MCM}$ and currently only $2.8 \mathrm{MCM}$ are available from artesian wells. The results also showed that one of the reasons for not using treated wastewater is a lack of experience in the planning and selection of wastewater treatment plant sites and of the capacity to match these with agricultural land that could reuse the treated wastewater. Demand management and improvements in living standards are the prerequisites necessary for the proper management of available resources. The results confirmed that the WEAP program provides a solid foundation to assist planners in developing recommendations for the management of water resources in the future, through the detection of hot spots on which to work.
\end{abstract}

Keywords: Balance; Scenarios; Water Resources Management; WEAP Model.

\section{Introduction}

The Arab world occupies $10 \%$ of the earth's land surface and comprises $5 \%$ of its population. However, it owns less than $0.5 \%$ of the renewable fresh water resources in the world [1]. Currently, Arab water consumption per capita is less than 1000 cubic meters per year and is expected to fall to $464 \mathrm{~m} 3$ per year in 2025. Most of the water in the Arab world originates from outside the region; with eight non-Arab countries controlling $85 \%$ of Arab water resources [2].

The water situation in the occupied Palestinian territories (oPt) is no better or worse than that encountered in the other Arab countries. The average daily water consumption of Palestinian citizens is 60 liters, which is much lower than the rates set by the World Health Organization as the minimum consumption of 100 liters of water per capita per day [3]. In developing countries, $90 \%$ of the sewage flows untreated into rivers, valleys, lakes, coastal areas and, sometimes, across political boundaries, and threatens the health, food security and access to safe drinking water and bathing water of its citizens [4]. In the West Bank, wastewater flows to valleys in two directions, to the west \& the north-east and towards the east. The West Bank generates about 70 million $\mathrm{m} 3$ of domestic wastewater annually, $65 \%$ of which is produced in the western and the north-eastern basins, which flow both towards Israel and to the eastern direction [5]. 
45 million $\mathrm{m} 3$ of sewage are produced annually in the western and the north-eastern regions of the West Bank, 17 million $\mathrm{m} 3$ of which is collected by sewage networks and disposed of to streams and valleys running towards Israel and the remaining 28 million $\mathrm{m} 3$ are disposed of in cesspits. This paper focuses on the Wadi Zomer catchment area, which produces about 6 million $\mathrm{m} 3$ of wastewater annually, or about $35 \%$ of the wastewater that crosses into Israel from the West Bank. [6]

The quality of the main source of water used in Israel and the Palestinian Territories, the Mountain Aquifer, is in acute danger. The main receiving stream bed in the area is Wadi Zomer. This wadi (valley) is used as a conduit for draining sewage from the towns of Nablus, Anabta, parts of Tulkarm and the villages located on the banks of the wadi. We roughly estimated that half of the sewage load generated between Nablus and Tulkarm infiltrates into the groundwater. In addition to the wastewater discharged into the wadi, a large portion of domestic sewage, from houses not connected to the central sewerage system, is contained in cesspits [7].

The Palestinian Authority faces a huge challenge, not only in meeting the water demand of the municipal, industrial and irrigation sectors, but also in providing water to meet the increasing needs for these sectors in the future. It is becoming clear that developing new water sources will not be enough to overcome these challenges; the solution must be tied to wiser use of current sources of water, through water demand management measures, water reuse and maintenance of good water quality.

This paper presents one application of the WEAP model in the Wadi Al Zomer watershed, and considers the untreated wastewater in the valley as a river. The applied model is used to evaluate and analyze the remaining balance and expected future scenarios for wastewater management, taking into account factors that may affect this demand until 2030, in order to ensure future sufficiency and sustainability of available water, in terms quantity and quality, to meet different long-term demands.

\section{Location}

The Wadi Zomer catchment area is located in the northern part of the West Bank. It is part of the catchment area representing the largest groundwater source in the region; the Mountain Aquifer. This area has some of the highest precipitation rates in the West Bank (average 600-700mm/year). However; it is characterized by a growing scarcity of water [8].

The upper area of the Wadi Zomer catchment is Nablus city and its surrounding villages, while the lower area of the catchment is represented by the city of Tulkarm and its surrounding villages [8]. The two main communities are shown in Figure 1.

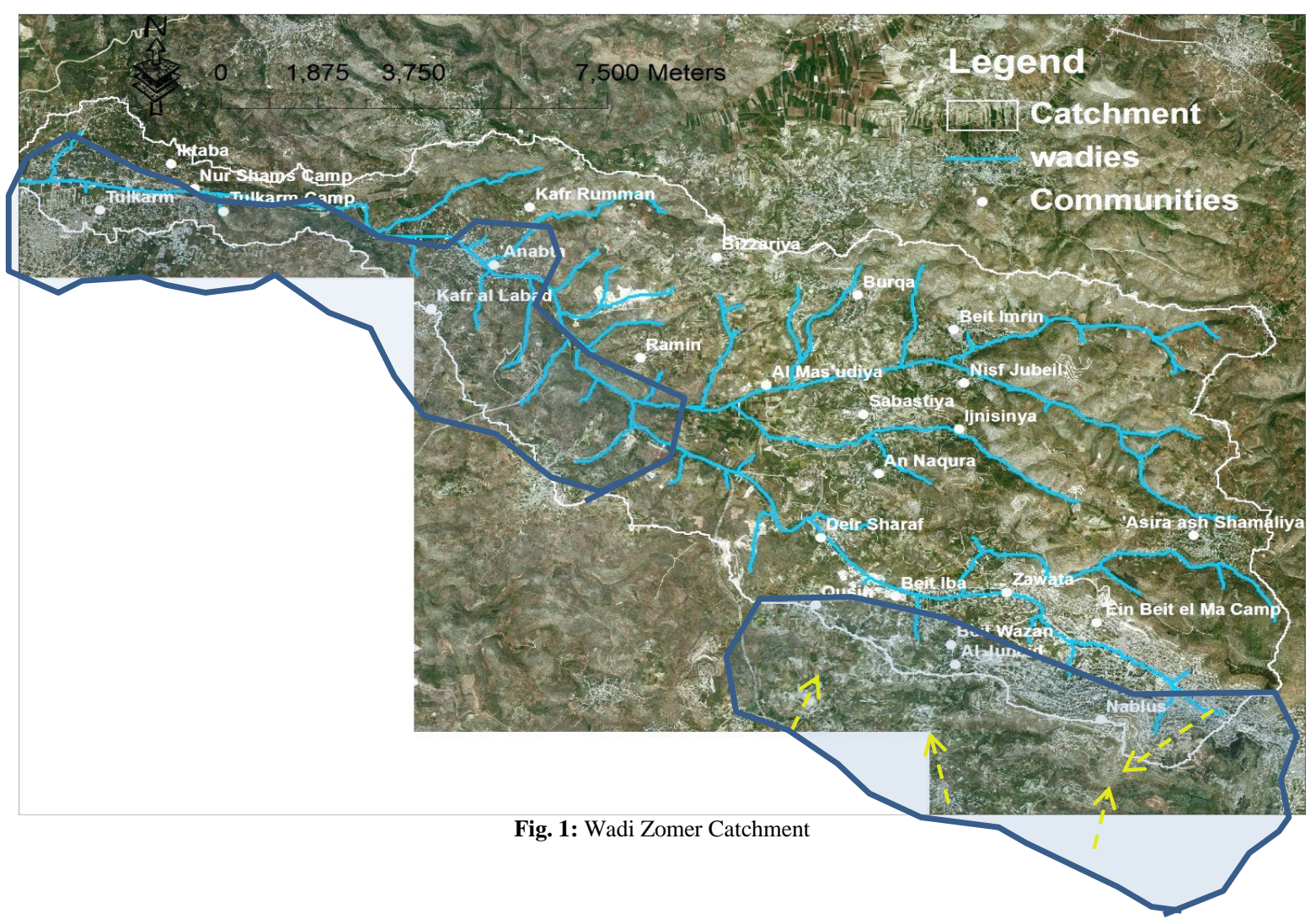




\section{Metrological data}

The climate in the area is Mediterranean, with moderately hot summers and moderatley warm winters. The mean annual maximum temperature is $22.3^{\circ} \mathrm{C}$. The average rainfall per annum amounts to $642 \mathrm{~mm}$. The potential evapotranspiration (PET) amounts to about 100mm during the months May - October. From December to March the PET is less than $50 \mathrm{~mm}$, whereas April and November are transition months, with a PET of about $75 \mathrm{~mm}[8]$.

\section{Topography and geological formation}

The study area lies on the western slopes of the West Bank, with plain areas to the west and mountainous terrain to the east. The elevation ranges from $50 \mathrm{~m}$ a.s.l. to $450 \mathrm{~m}$ a.s.l. Wadi Zomer stretches from the Green Line to Deir Sharef. The bottom of the valley is at an elevation of between $50 \mathrm{~m}$ a.s.l. and $200 \mathrm{~m}$ a.s.l. Topographically the syncline is asymmetrical, with a gently dipping western limb and a steep eastern one.

\section{Water resources system}

The main source of domestic water in the West Bank derives from the shallow and deep water bearing formations of the Mountain Aquifer. This aquifer is commonly considered in three parts, named the Western, North-Eastern and Eastern Basins. The Tulkarm district lies nearly entirely in the Western basin, whereas the Nablus district is located in all three basins.

Wadis have a typical temporary runoff pattern, with surface runoff only during the winter season (from the months of November to March). However, Wadi Zomer shows permanent runoff throughout the year, with domestic and industrial wastewater, mainly from Nablus in the upper catchment area and from Anabta and Tulkarm in the lower catchment area, during the dry season [9].

The total water consumption in the project area amounted to about 3 million $\mathrm{m}^{3}$ in 2006 . We consider average water losses in the range of $40 \%$ results in water production of more than 4.6 million $\mathrm{m}^{3}$. Based on the metered water consumption and the population figures provided by the Palestinian central Bureau of Statistics (PCBS), the average per capita water consumption is $68.8 \mathrm{l} / \mathrm{c} / \mathrm{d}$. [10].

\section{Agricultural areas land use}

Nablus West WWTP potential effluent irrigation areas can be found nearby the site. The first area of interest stretches along the WWTP site itself, covering an area of about 35 ha. Technically, being situated directly in the plain of the valley, the application of effluent would be relatively uncomplicated.

Wider and more extended agricultural areas are located near the village of Sabastia. However, from a geographical point of view, before reaching this area the hill dividing both plains has to be crossed. This is an area of approximately 250 ha.

The available 285 ha ( 35 plus 250 ha) of land can be served in its entirety once the WWTP has been commissioned. However, by 2020 additional areas of 100-200 ha will be needed to absorb all the effluent generated.

Currently, all areas in question are rain-fed; no irrigation infrastructure exists. However, the potential irrigation areas are located at higher elevations than the treatment plant sites, so would require effluent pumping [11].

From Nablus West WWTP the anticipated volume of treated wastewater at start up is $11,472 \mathrm{~m} 3$ per day in the year 2013. By 2035 WEAP model estimated that $27,377 \mathrm{~m} 3$ of effluent per day will be generated.

Considering the effluent generated and the proposed crop composition, the potential irrigation areas identified might be fully served by these flow rates. However, as already indicated, for Nablus West WWTP additional area is required in the future. As no other freshwater resources are available, effluent will be the only source of irrigation water. This will require the development of a proper irrigation water and fertilizer management system.

\subsection{Crop composition}

The composition of future cropping has been estimated on the basis of anticipated profitability, market needs and the experience of farmers in the region. Accordning to national wastewater effluent standards, regulations and legal restrictions or recommendations by the Ministry of Agriculture (MOA), vegetables and olives were excluded from the future cropping pattern used in the model [12]. The proposed main crops to be irrigated with effluent are barley, alfalfa, Sudan grass and stone fruits, such as almonds. 


\section{Water evaluation and planning system}

The Water Evaluation and Planning (WEAP) software package was selected for the purpose of this study. WEAP is a practical tool for water resource planning, as it considers both water supply and demand issues in addition to water quality and ecosystem preservation, as expected of an integrated approach to basin management [13]. The model is semi-theoretical and needs calibration and verification [14].

WEAP is a tool used to examine alternative water development and management strategies [15]. The model simulates water system operations within a river system, using basic water accounting principles based on a user-defined time step; it computes water mass balance for every node and link in the system for the simulation period [16]. Simulation allows the prediction and evaluation of "what if" scenarios and water policies, such as water conservation programs, demand projections, hydrologic changes, new infrastructure and changes in allocations or operations [17].

For the purpose of this paper, the WEAP model is adapted to simulate the wastewater situation in the Wadi Zomer catchment, where wastewater reuse represents an important possible management option.

\subsection{Wadi Zomer watersheds modeling}

Running the WEAP program requires the input of a large volume of data, for every element in the network. The data structure and level of detail used can easily be customized to meet the requirements of a particular analysis and to reflect the limits imposed when data is limited [18]. To set up the model, monthly time steps were used in the hydrologic simulation, for the following reasons: (1) compatibility with significant hydrologic process time periods and (2) the existence of the data in a monthly framework. The WEAP model representation wadi Zomer watershed is shown by Fig. 2.

In the WEAP model, we assumed that each main community group is a demand node, supplied by water and returns the wastewater to the nearby wadi. This wadi is known locally as Wadi Zomer and it flows continuously, forming a river of wastewater from nearby communities.

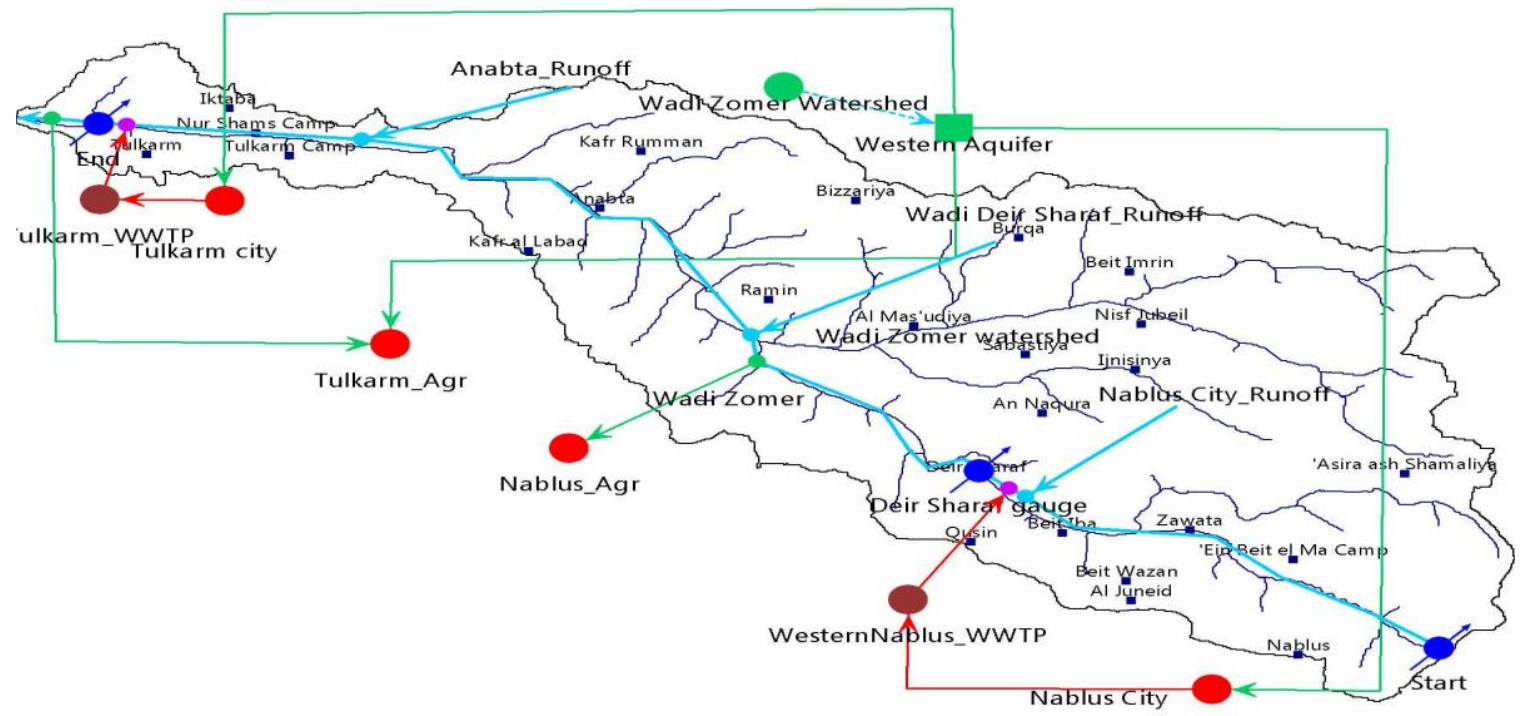

Fig. 2: The WEAP Model Representation Wadi Zomer

Demand site priority, which tells the WEAP the order in which water should be allocated to different users, is an important input. For WWA, domestic demands were given priority over agricultural demands, whenever domestic and agricultural demands competed for the same water resource.

\subsection{Model calibration and validation}

The goal of model calibration is to adjust the parameters so that the model solutions fit the observations in an optimal fashion. Model calibration was done manually, through trial and error, seeking to minimize the root mean square error (RMSE), and to maximize the correlation coefficient, R. WEAP's watershed hydrology module approximates critical hydrologic processes making use of a few key parameters. These include; a plant/crop coefficient (Kc), which, in combination with an estimation of potential evapotranspiration, determines evaporative losses; a conceptual runoff resistance factor (RRF), related to factors such as leaf area index and land slope, with higher RRF values representing reduced rapid surface runoff; and water-holding capacity and hydraulic conductivity parameters that determine the slower, interflow response. A partitioning fraction (preferred flow direction) determines whether water moves horizontally or vertically. 
The year 2006 data was used for model calibration and the year 2007 data was used for model validation. For this research, naturalized stream flows, from the selected stations, were compared with the results of the model.

Calibration was implemented using flow measurements that were taken in previous years. Flow data is from a report by House of Water and Environment, as presented in Table 1. The location of flow meters is shown in Figure 4.

On the other hand, flow measurement for the Deir Sharaf area was provided by the officer of Deir Sharaf pilot wastewater treatment plant: $600 \mathrm{~m} 3 / \mathrm{hr}$, equivalent to $14,400 \mathrm{~m} 3 /$ day.

In general, effluent utilization rates did not exceed $70 \%$ of the available effluent, due to periods of zero/low demand (December-February) and the seasonal crop demand variability. In the later stages water utilization rates decreased because extra effluent was available and available land was limited (Nablus West only).

This means about 30-40\% of the effluent needed to be disposed of/reused, especially in winter time. As such, we propose that effluent be discharged into adjacent wadis, at least during the initial operational phases of the WWTPs.

\section{Management alternatives and scenario analysis}

\subsection{Reference scenario}

The Current Accounts is the dataset from which the scenarios are built. Scenarios explore possible changes to the system in future years beyond the Current Accounts year. A default scenario, the "reference" or "business-as-usual" one, carries forward the Current Accounts data into the entire specified project period and serves as a point of comparison for the other scenarios in which changes are made to the system data. The current situation (2006) is extended to the future (2007-2030). No major changes are imposed in this scenario. The only one analyzed is a situation without the development of large irrigation systems and with MAO Transfers.

\subsection{Other scenarios}

Scenario 1: Represents the current situation, in which wastewater produced is not used and flows to the Israeli side, to be treated and reused by Israel, with no benefit for Palestinians.

Scenario 2: Represents the situation in which a WWTP is built west of Nablus and treats the wastewater produced by the western part of Nablus and the surrounding villages, represented in the model by the node "Nablus City". The treated wastewater is used in nearby agricultural areas, represented in the model by the demand node "Nablus_Agr". In contrast, the wastewater produced in the Tulkarm area is not treated and is allowed to flow to the Israeli side.

Scenario 3: A new WWTP constructed near Tulkarm city to treat waste water from the Tulkarm area and the treated effluent is used in Tulkarm agricultural areas represented in the model by the demand node "Tulkarm_Agr".

\section{Results}

\subsection{Projection of wastewater from Palestinian communities}

The model shows rates of wastewater flowing, and expected to flow in the coming years, to WWTPs as following: Figure 3 shows the wastewater generated in the study area, which is expected to reach 14.8 million m3 per year by 2035. The WEAP model was built and calibrated based on wastewater flow rates calculated through a complex process of referring to most of the available studies between 2006 and 2014 and all actual onsite measurements in the valley. The volume of wastewater generated from Western Nablus Province in 2035 is predicted to be about 8 million m3, which represents $54 \%$ of that produced in the entire study area.
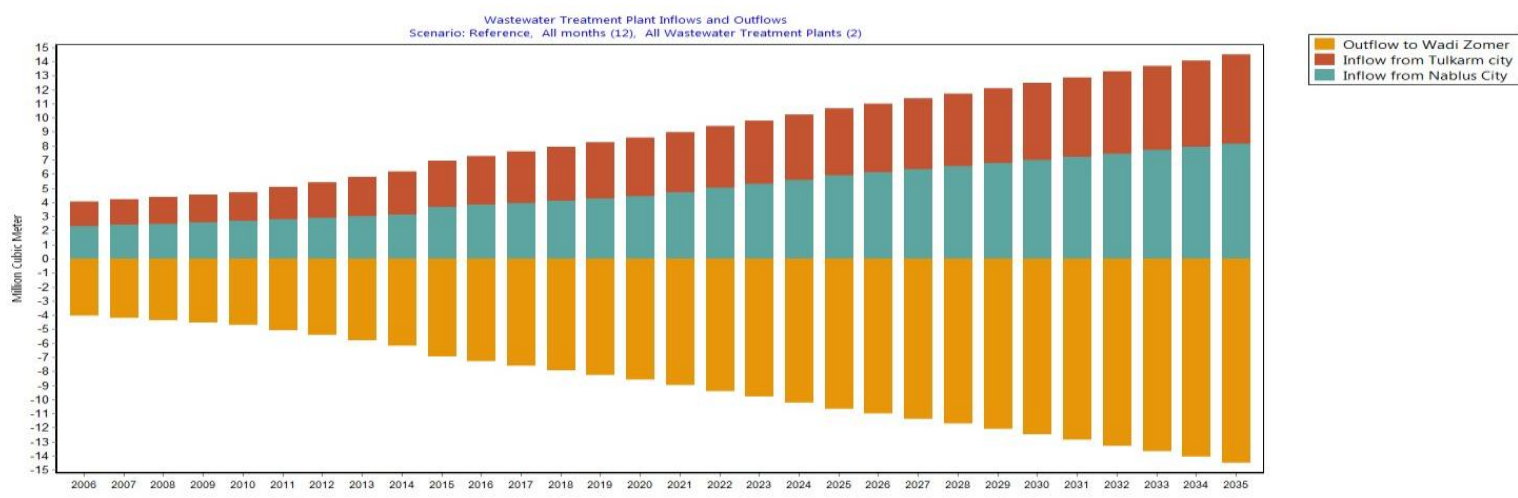

Fig. 3: Wastewater Treatment Plant Inflows and Outflows 
Figures 4 and 5 illustrate the agricultural land needs of water in the study area, which are estimated at 17.5 MCM, while the farmland in Nablus area needs only 1.5 MCM, and in Tulkarm area needs about $16 \mathrm{MCM}$ annually.
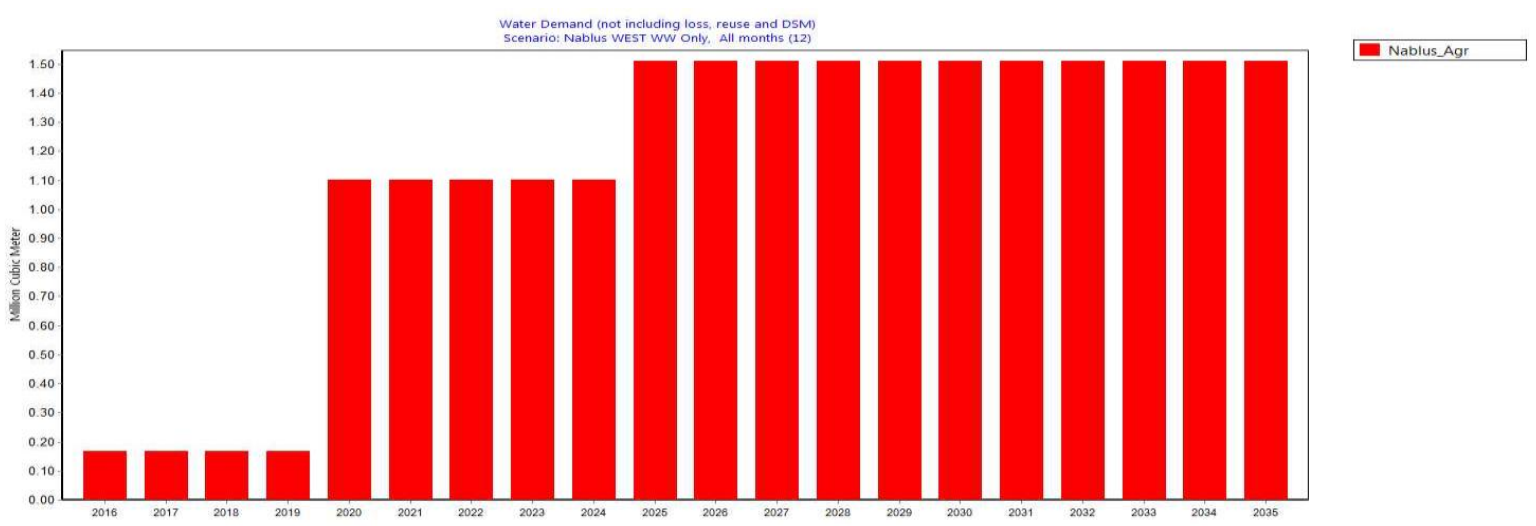

Fig. 4: Nablus' Irrigation Water Demand
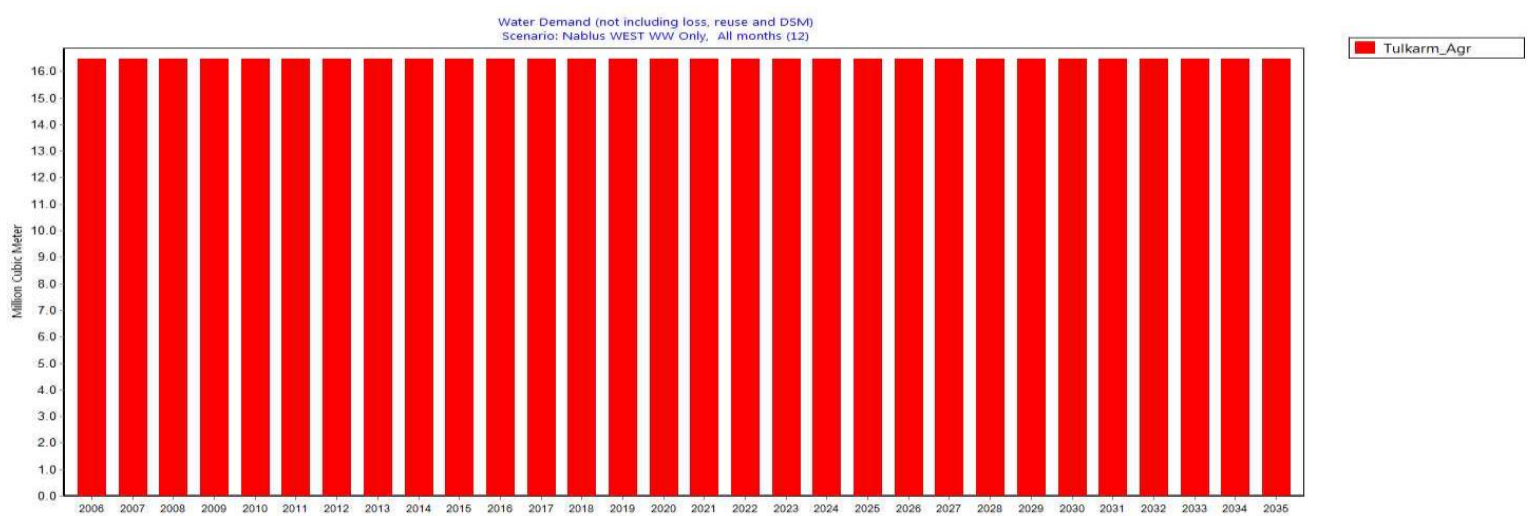

Fig. 5: Tulkarm Irrigation Water Demand

Scenarios 1: The WEAP model was designed to include three scenarios, in order to simulate reality and find the best options that can be applied to achieve successful management and sustainability of water resources.

Scenario 1: Represents the current situation, in which the wastewater produced is not reused in the West Bank and flows to Israel, to be treated and reused by there, without any benefit for Palestinians.

In this scenario no WWTP will be constructed on the Palestinian side and wastewater will flow, without any treatment in the wadi, to Israel. The Palestinian side pays the waste water treatment costs to the Israeli side, which may amount to about 6.35 million dollars per year in 2035, taking into consideration the current price of 44 cents per cubic meter. In this scenario Palestinian agricultural land does not benefit from effluent reuse and will remain without an additional water source for irrigation.

Figure 6 shows that the only water source available for agriculture in the study area is fresh water from the aquifer, with an estimated capacity of 2.8 million $\mathrm{m} 3$ per year. The estimated water deficit in this scenario is about $15 \mathrm{million} \mathrm{m} 3$ annually.
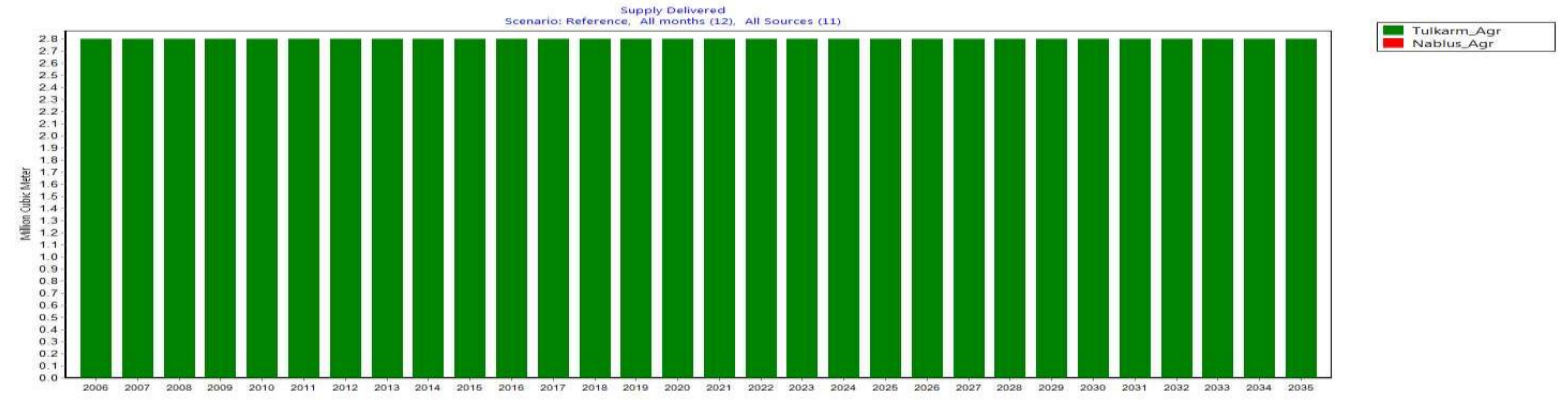

Fig. 6: Water Supplied To Agriculture in the Current Situation from Groundwater Wells

Scenario 2: Represents the situation in which a waste water treatment plant is to be built west of Nablus to treat wastewater produced in the western part of Nablus city and surrounding villages, represented in the model by the node "Nablus City". The treated wastewater is used in nearby agricultural areas, represented in the model by the demand 
node "Nablus_Agr". In constrast, wastewater produced in the Tulkarm area is not treated and is discharged to the wadi on the Israeli side.

This scenario reflects the Palestinian Water Authority's approved plan, which includes constructing a WWTP serving the western Nablus area, with untreated wastewater delivery lines serving the Tulkarm area running towards Israel.

Agricultural land in the Nablus area needs $1.8 \mathrm{MCM}$ of water for irrigation annually, while farmland in the Tulkarm area needs 15 million $\mathrm{m} 3$ per year.

Adopting this scenario will lead to the loss of $87 \%$ of the wastewater generated in the study area to Israel. To enable the Palestinian farmers to benefit from the $72.5 \%$ (27.5\% used in the only available Agriculture land) of treated water from Nablus treatment plant, it would require the implementation of an agriculture infrastructure project for trunk carrier lines, pumps and reservoirs.

Figure 7 shows the estimated WW flow rates in the valley once Nablus WWTP is operational. The yellow line shows that $9 \mathrm{MCM}$ will cross the Israeli border. Figure 8 shows that Nablus agricultural land would get $1.5 \mathrm{million} \mathrm{m} 3 \mathrm{per}$ annum of treated WW and that Tulkarm farmland would remain dependent on 2.8 MCM per year from groundwater.
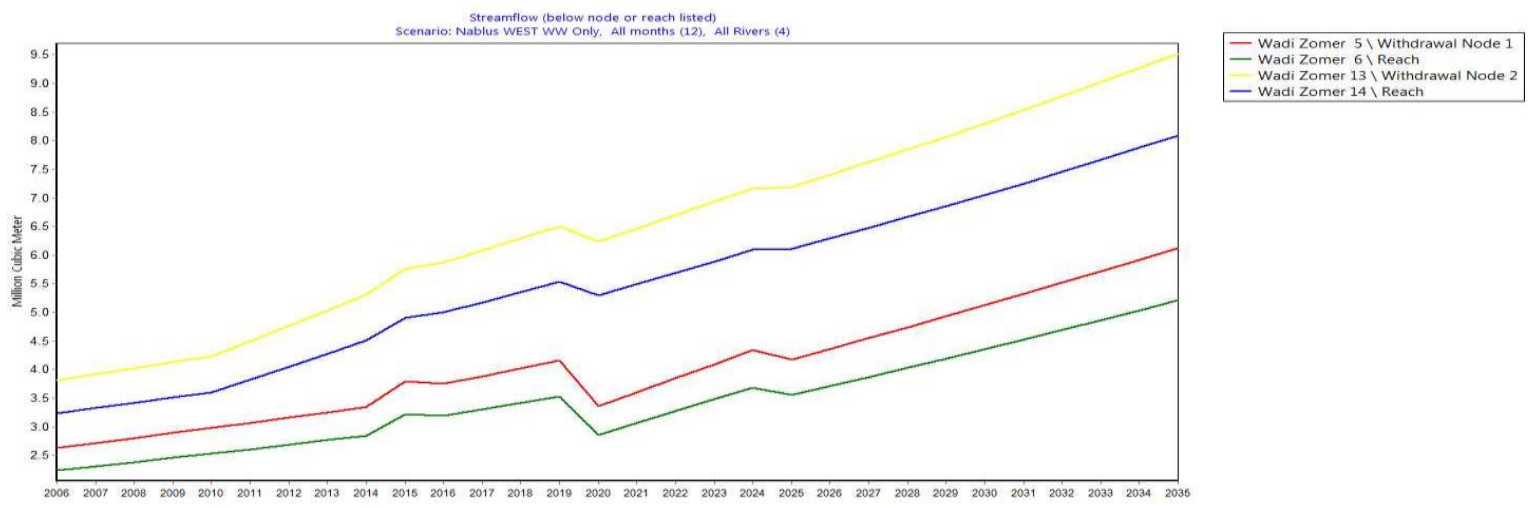

Fig. 7: Stream Flow Rates in Wadi Zomer.

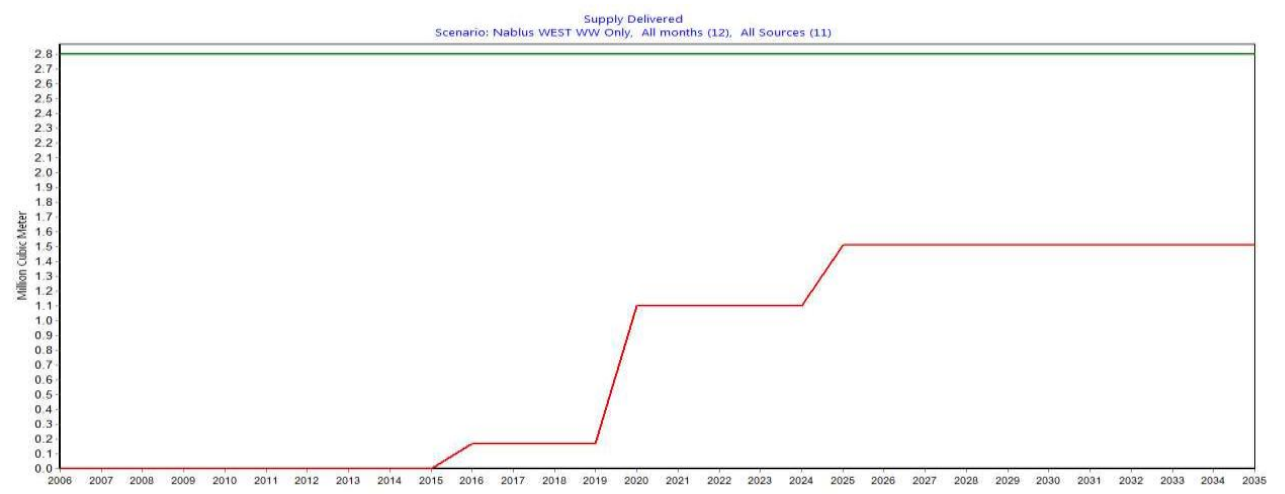

Fig. 8: Water Supplied To Proposed Agricultural Areas

In this scenario, there will still be a water deficit of 13.5 MCM for irrigation demand in the study area, as most of the wastewater will continue to cross the border to Israel. Only 1.5 MCM of treated wastewater will be used for agriculture in the Nabulus area. Reuse of the remaining $6 \mathrm{MCM}$ will be costly as it requires investment in a full infrastructure scheme to transfer the treated water to remote areas, as shown in Figure 9 that Nablus farmland area have got all their treated wastewater needs, but remained the Tulkarem area need to 14.5 million cubic meters.
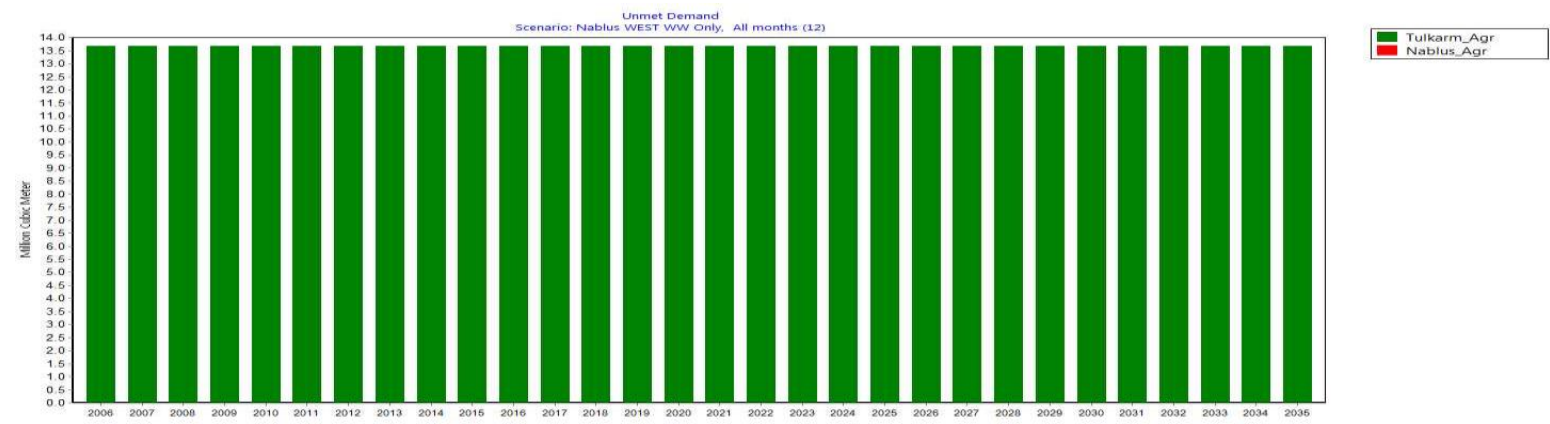

Fig. 9: Unmet Agricultural Water Demand, Scenario 2 
Scenario 3: Represents the situation in which a treatment plant is built to the west of Nablus to treat wastewater produced in the western part of Nablus city and surrounding villages, represented in the model by the node "Nablus City". The treated wastewater is used in nearby agricultural areas, represented in the model by the demand node "Nablus_Agr". In addition, another treatment plant is built next to Tulkarm city, to treat wastewater from the Tulkarm area and the treated effluent is used in Tulkarm agricultural areas, represented in the model by the demand node "Tulkarm_Agr".

Figure 10 below illustrates wastewater flow rates along the valley where there is a four-point measurement. The red line shows that six million $\mathrm{m} 3$ of wastewater flows into the valley from Nablus treatment plant, because of a lack of arable land. The yellow and blue lines show that wastewater flow across the Israeli border will be zero in the case of two treatment plants being establishment.
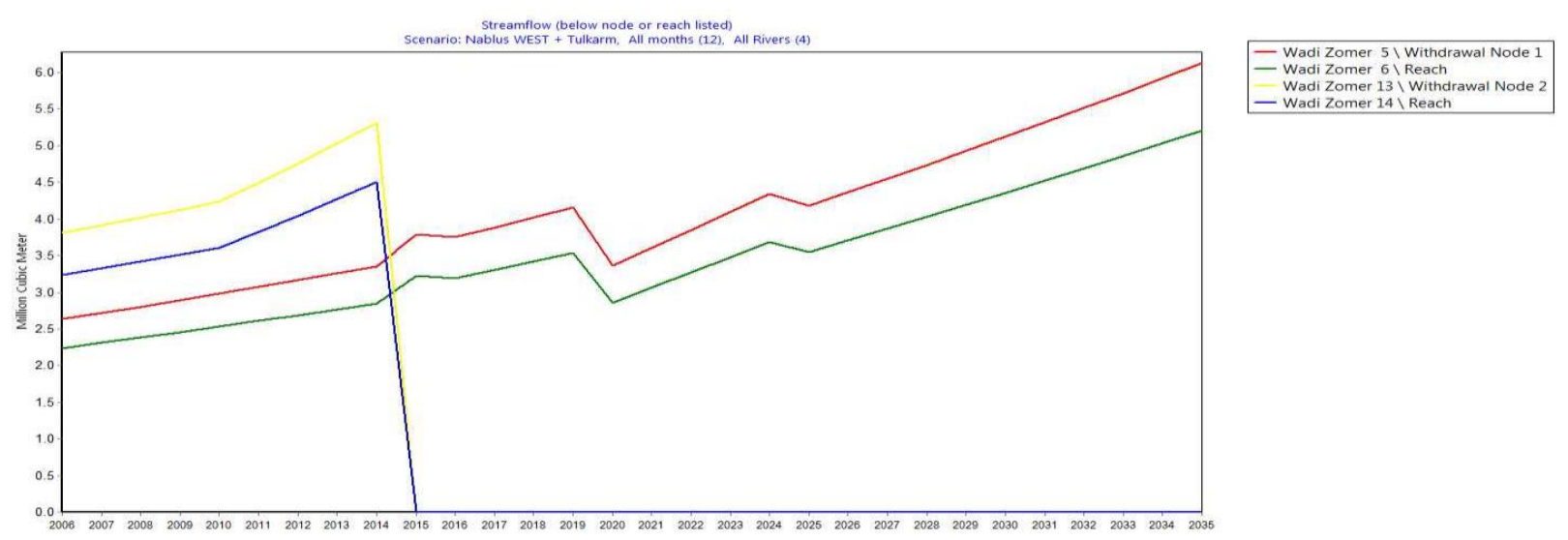

Fig. 10: Stream Flow.

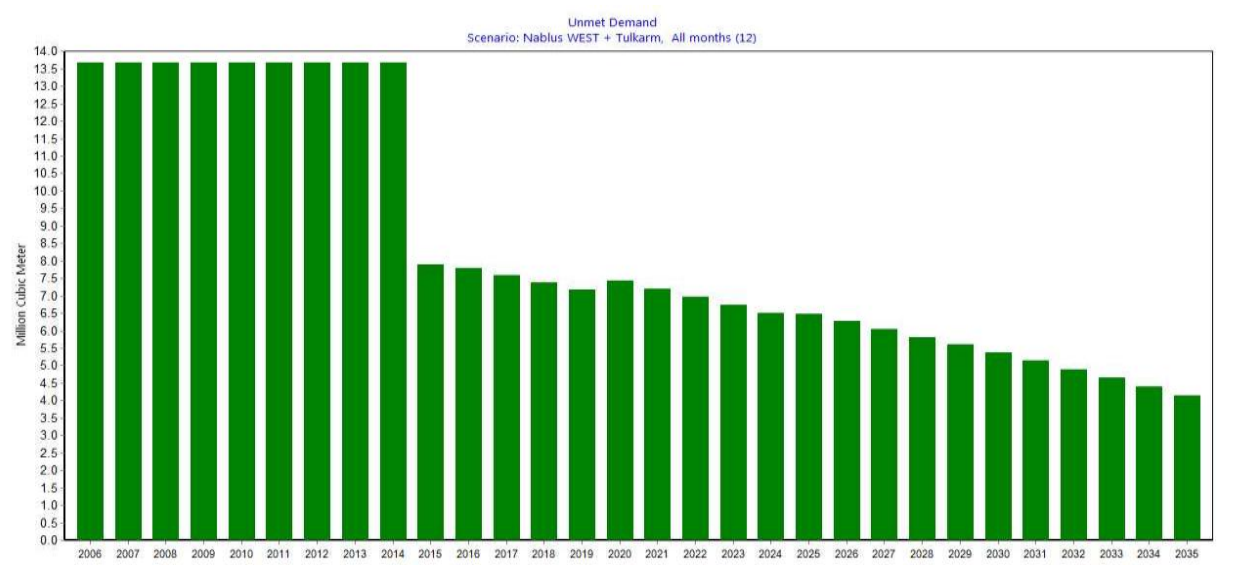

Fig. 11: Water Deficit Demand for Agricultural In Scenario 3

Figure 11 below shows that the irrigation demand for the Tulkarm Agricultural area is about 13.5 MCM in 2014. If Tulkarm WWTP were to be built, the forecast deficit of 4 MCM in 2035 would need to be supplemented. Nablus agricultural area needs 1.5 million cubic meters for irrigation and Nablus west WWTP will cover this amount.

\section{Conclusions and recommendations}

Water resources Management in surface watersheds is important in order to achieve high efficiency in water demand management. The estimated water demand for irrigation purposes in the study area is $17.5 \mathrm{MCM}$. However; there are only 2.8 million cubic meters available from groundwater sources, therefore most of the land is threatened by desertification if no concrete steps are taken to provide the required water for agriculture from unconventional water resources.

The untreated wastewater flow rate in the Alzomer stream in 2013 was about 6 million cubic meters. Untreated wastewater that flows from the Palestinian territories to Israel is treated there, at the expense of the Palestinians, and is reused for irrigation purposes in Israel. The expected annual volume of wastewater to be generated by 2035 in the study area is 14.8 million cubic meters, and this amount is sufficient to cover the agricultural water demand in the study area, if treated and used efficiently.

A Wastewater Treatment Plant for communities in the province of Nablus West was constructed, at a cost of 30 million Euros, and the Plant became operational in 2014. This plant will treat about 3 million cubic meters in 2014 and is designed to treat 8 million cubic meters by 2035. Farmland in the West Nablus province needs only 1.5 million cubic 
meters per annum and 6.5 million cubic meters needs to be transferred annually to be reused in other areas. The cost of the transfer system, reservoirs, carrier lines and pumps for this to work is significant. The alternative is to discharge to the existing carrier line for untreated wastewater, wasting money in unnecessarily treating 6.5 million cubic meters of wastewater annually.

The Palestinian side is currently paying about $\$ 2.2$ million annually to the Israeli side for treatment of 6 million cubic meters of wastewater that flows from the West Bank to Israel and this will increase to $\$ 6.4$ million by 2035. The Israelis sells treated wastewater to local farmers without an agreement with or recompense to the Palestinian side who provide the raw material.

The construction of two WWTPs in the study area, the first with an annual capacity of 1.5 million cubic meters, to serve part of the western province of Nablus, and a second, with a capacity of about 13 million cubic meters per annum, in the Tulkarm area, is the best solution to take advantage of all treated WW to be reused in agriculture locally. This would also preserve available groundwater for drinking purposes and would create new jobs in the agricultural sector.

\section{References}

[1] Jean Khouri. 2007. Sustainable development and management of water resources in the Arab region. Water Resources Division, The Arab Center for the Studies of Arid Zones and Dry lands, Damascus, Syria.

[2] Emirates Center for Strategic Studies and Research. 2009. Future Demographic Challenges in the Arab World, 1246-1682, Scholarly Journals, Abu Dhabi, United Arab Emirates

[3] Hassan, M. A. and McIntyre, G. 2012. Palestinian Water: Resources, Use, Conservation, Climate Change, and Land Use. Digest of Middle East Studies, 21: 313-326. doi: 10.1111/j.1949-3606.2012.00175.

[4] Corcoran, E., C. Nellemann, E. Baker, R. Bos, D. Osborn, H. Savelli (eds). 2010. Sick Water? The central role of wastewater management in sustainable development. A Rapid Response Assessment. United Nations Environment Programme, UN-HABITAT, GRID-Arendal. www.grida.no

[5] Aya, R. Arfat. 2007. Integrated Water Resources Planning for A water-Stressed Basin in Palestine,[http://www.najah.edu/sites/default/files/Centers_document/Integrated_Water.pd].

[6] Yaqob, Eyad. 2012. Wastewater sector vision, policy and strategy internal Report, Palestinian Water Authority, Ramallah, West Bank, Palestinian Authority.

[7] Tal, Alon,Abed Rabbo, Alfred. 2010. Water wisdom: Preparing the groundwork for cooperative and sustainable water management in the Middle East. New Brunswick, N.J: Rutgers University Press.

[8] Alon Tal, Nader Al Khateeb, Lior Asaf, Amjad Assi ,Alice Nassar, Muath Abu Sadah, Avital Gasith, Jonathan Laronne, Zeev Ronen, Yaron Hirshkowitz, Dima Halawani, Neta Nagouker, Roey Angel, Hila Akerman, Mousa Diabat and Adam Abramson. 2007. Watershed Modeling: Bio Monitring and Econmoic anaylsis for transboundary streams. The Arava Institute for Environmental Studies (AIES), Israel.

[9] Palestinian Water Authority. 2012. STATUS REPORT OF WATER RESOURCES IN THE OCCUPIED STATE OF PALESTINE, Ramallah, West Bank, Palestinian Authority

[10] Palestinian Central Bureau of Statistics (PCBS), Projected mid -Year Population for Governorates by Locality 2004-2006.Available online at: [http://www.pcbs.gov.ps]. Accessed date [15.10.2011].

[11] Haddad, Marwan. 2012. Evaluation of gradual hydroponic system for decentralized wastewater treatment and reuse in rural areas of Palestine. International journal of agricultural and biological engineering (1934-6344), 5 (4), p. 47.

[12] Institutional and Legal Framework for Wastewater Reuse of Palestine. 2011. Technical Assistance on Wastewater Reuse and Storm water Harvesting, Palestinian Water Authority, and Austrian Development Agency.

[13] SEI .2007. WEAP: user guide for WEAP21. Stockholm Environment Institute, Boston.

[14] Abrishamchi A, Alizadeh A, Tajrishy M .2007. Water resources management scenario analysis in the Karkheh river basin, Iran using the WEAP model. Hydrol Sci Technol 23(1-4):1-12.

[15] SEI .2005. WEAP user's guide. Stockholm Environment Institute, Boston

[16] Yilmaz B, Nilgun B, Harmancioglu. 2010. An indicator based assessment for water resources management in Gediz River basin, Turkey.Water Resour Manag 24(15):4359-4379. Doi: 10.1007/s11269-010-9663-3 http://dx.doi.org/10.1007/s11269-010-9663-3.

[17] Mutiga J, Shadrack T, Mavengano Su, Zhongbo TW, Becht R. 2010. Water allocation as a planning tool to minimize water use conflicts in the upper Ewaso Ng'iro north basin, Kenya.Water Resour Manag 24(14):3939-3959. Doi: 10.1007/s11269-010-9641-9 http://dx.doi.org/10.1007/s11269-010-9641-9.

[18] Yates D, Purkey DR, Sieber J, Huber-Lee A, Galbraith H. 2005b. Weap21-a demand-, priority-, and preference-driven water planning model: Part 2, aiding freshwater ecosystem service evaluation. Water Int 30(4):501-512 http://dx.doi.org/10.1080/02508060508691894. 